\title{
Dental Pulp Stem Cells: A Promising Tool for Bone Regeneration
}

\author{
Antonio Graziano • Riccardo d'Aquino • \\ Gregorio Laino • Gianpaolo Papaccio
}

Published online: 6 May 2008

(C) Humana Press 2008

\section{Erratum to: Stem Cell Reviews}

DOI 10.1007/s12015-008-9013-5

The authors of the above article are listed in incorrect order in the original publication; the proper order is Antonio Graziano, Riccardo D'Aquino, Gregorio Laino, and Gianpaolo Papaccio.

The online version of the original article can be found at http://dx.doi. org/10.1007/s12015-008-9013-5.

R. d'Aquino · G. Laino

Dipartimento di Discipline Odontostomatologiche,

Ortodontiche e Chirurgiche,

Secondo Ateneo di Napoli (Italy),

Naples, Italy

G. Papaccio

Dipartimento di Medicina Sperimentale,

Sezione di Istologia ed Embriologia,

Secondo Ateneo di Napoli (Italy),

Naples, Italy

A. Graziano · R. d'Aquino

TESLAB s.r.l.,

Cava dè Tirrreni,

Salerno, Italy

A. Graziano $(\bowtie)$

via Bonito 23,

80129 Naples, Italy

e-mail: deagra@libero.it 